\title{
Organic versus mineral fertilization: Assessing of yield and quality of durum wheat in marginal lands
}

\author{
Ida Di Mola, ${ }^{1}$ Lucia Ottaiano, ${ }^{1}$ Adriana Sacco, ${ }^{2}$ Mauro Senatore, ${ }^{3}$ Mauro Mori ${ }^{1}$ \\ ${ }^{1}$ Department of Agricultural Sciences, University of Naples Federico II, Portici (NA); ${ }^{2}$ National Council of \\ Research, CNR-IPSP, Portici (NA); ${ }^{3}$ Samagri Start up Innovativa srl, Cava de' Tirreni (SA), Italy
}

\section{Highlights}

- Organic fertilization based on roasted leather was compared to mineral fertilization in three marginal environments for two years.

- Effect of organic fertilization on wheat yield, grain quality and nitrogen use efficiency was site-specific.

- Yield of plants organically fertilized was lower than mineral fertilization in the two environments less fertile and with a high clay content.

- Nitrogen use efficiency of organic fertilization was lower than mineral in the two environments less fertile and with high content of clay.

- Grain protein and gluten percentage were lower in the site with higher rainfall.

\begin{abstract}
Durum wheat is often cultivated in marginal areas with great management difficulties. Organic fertilization is a sustainable agricultural practice that allows preserving the environment, but its limit can be the reduction of yield and quality of crops, also in cereals. The aim of research was to evaluate the effects of the organic fertilization on yield and quality of Simeto, a variety of durum wheat, cultivated for two years in three different sites of the internal hill of Campania Region (San Giorgio la Molara, SGM; Ariano Irpino, AI; Sant'Angelo dei Lombardi, SAL). SGM was a sandy-clay-loam soil, with high fertility, while AI and SAL were clay soil.

The organic fertilization (ORG), based on roasted leather, was compared to mineral fertilization (MIN) and the not fertilized treatment (N0). In SGM, crop growth rate (CGR) and leaf area index (LAI) were significantly higher than AI and SAL until the
\end{abstract}

Correspondence: Lucia Ottaiano, Department of Agricultural Sciences, University of Naples Federico II, 80055 Portici (NA), Italy.

E-mail: lucia.ottaiano@unina.it

Key words: Durum wheat; nitrogen management; grain quality; nitrogen use efficiency; organic fertilization; sustainable agriculture.

Received for publication: 26 February 2021.

Revision received: 1 June 2021.

Accepted for publication: 2 June 2021.

${ }^{(C)}$ Copyright: the Author(s), 2021

Licensee PAGEPress, Italy

Italian Journal of Agronomy 2021; 16:1855

doi:10.4081/ija.2021.1855

This article is distributed under the terms of the Creative Commons Attribution Noncommercial License (by-nc 4.0) which permits any noncommercial use, distribution, and reproduction in any medium, provided the original author(s) and source are credited. flowering (about 2- and 4-fold more, respectively). MIN and ORG significantly boosted CGR compared to N0, while for LAI, ORG was never different from N0. The two-years value of yield was 3.0 $\mathrm{t} \mathrm{ha}^{-1}$; in SGM, it reached $4.2 \mathrm{tha}^{-1}$, and it was $54.6 \%$ more than the mean value of AI and SAL, while N0 was not different from MIN of AI and SAL. ORG yield was lower and not different from NO in AI, where the lowest values of 1000 kernels weight, and hectolitre weight were also recorded. MIN and ORG increased the number of spikes per square meter: $27.0 \%$, and $12.8 \%$ over N0, respectively, but ORG showed an $11.2 \%$ decrease compared to MIN. The 1000 kernels weight reached the highest values in SAL, without differences between N0, MIN, and ORG. The values of protein and gluten percentage were highest in AI and SGM (about $13.5 \%$, and $11.7 \%$, respectively), but without differences between ORG and MIN in the 3 sites for protein percentage. The worst value of the vitreousness was recorded in SAL (52.3\%), six-fold more than that of AI (8.2\%), probably due to the high rainfall.

NUE reached the highest value in SGM in the first year, when it was significantly different from AI and SAL (0.036 vs 0.030 $\left.\mathrm{t} \mathrm{kg}^{-1}\right)$.

Overall, the effect of nitrogen fertilization type results sitespecific; indeed, organic fertilization had the same performance of mineral in the site with better soil (low clay content, high nitrogen, and organic matter content) and climate conditions.

\section{Introduction}

Durum wheat (Triticum turgidum L. subsp. durum) is one of the most economically important crops cultivated worldwide on about 30-35 million hectares, but especially in the Mediterranean basin where it is used to produce foods, such as pasta, couscous, bread and bulgur (David et al., 2005).

In Europe, Italy has the largest area dedicated to cereals, especially durum wheat. It is the main cereal crop in Italy, with about 1.2 million hectares and production of about 39 million quintals per year (ISTAT, 2020; http://dati.istat.it). Almost 70\% of the cultivation is concentrated in Southern Italy where meteorological factors positively influence crop yield (Ventrella et al., 2016). 
The use-destination of durum wheat is typically the production of pasta, which is an excellence of the agro-industry of Southern Italy and, in particular, of Campania Region, where the durum wheat is mainly cultivated in the internal areas, where in the past it has constituted a source of income for farmers. Its added value is strictly linked to the quality and typicality of the raw material. These inland areas are typically identified as marginal lands, that is unproductive or unsuitable areas for crop production due to poor soil properties, bad quality underground water, drought, undesired topology, unfavorable climatic conditions; consequently they have no or little potential of profitability for conventional food crops (Mehmood et al., 2017).

The difficulties of managing crops in these marginal areas and the subsidies reductions for durum wheat are causing a progressive abandonment of this cultivation and consequently of the areas where it is cultivated. Currently, efforts are being made to enhance the typical productions of these areas, such as durum wheat, also through the application of innovative and eco-sustainable cultivation techniques, in order to increase the farmer income. Organic cultivation may be an eco-sustainable production process, that also has the advantage to preserve the environment and improve soil fertility and stability. But it can sometimes result in several management problems, especially regarding weeds control and fertilization. Therefore, one of the main limits of organic farming, also in cereal production, is the possible reduction in yields (Berry et al., 2002). Seufert et al. (2012) observed that yield of grain cultivated in organic farming is $30 \%$ lower than that obtained in conventional farming, due to multiple limiting factors, as well as resource availability (Kho, 2000). Moreover, the nutritional and technological quality of wheat can widely vary depending on genotype, environment, crop management, and their interactions. Studies comparing conventional and organic management indicated that a farming system can influence some parameters such as proteins, gluten, starch, mineral elements, organic acids, and lipids, but the results are sometimes contrasting, also due to the large variability in environmental factors and production conditions (Mader et al., 2007). In addition, the different agronomic response of species to organic fertilization also depends on types of fertilizers and their mineralization rate. Organic fertilizers can be vegetal- or animal-based; these last ones are protein-rich materials, with high potential as $\mathrm{N}$-fertilizers (Mondini et al., 2008). Among animal by-products, there is roasted leather, derived from leather-making industrial processes, and allowed to be used in the EU as fertilizers and soil conditioners in organic farming (Commission Regulation (EC) No. 889/2008). Roasted leather is obtained by the pre-tanning process of hides; it contains low molecular weight proteins and can be considered as a rich source of $\mathrm{C}$ and $\mathrm{N}$ for the production of organic fertilizers (Ravindran et al., 2013).

To date, information about the effect of different agriculture practices on the nutritional value and quality of durum wheat pasta is very limited (Nocente et al, 2019).

Therefore, the aim of this research was to assess the effects of an organic fertilizer, based on roasted leather, compared to mineral fertilization and not fertilized, on the yield and quality of Simeto, a variety of durum wheat cultivated in three marginal areas of the Campania Region internal hill.

\section{Materials and methods}

\section{Experimental design and crop management}

The experimental design was a factorial combination between three different sites of the internal hill of Campania Region (South Italy) and three different nitrogen fertilization strategies. The experimental sites were: i) San Giorgio la Molara (BN), SGM; ii) Ariano Irpino (AV), AI; iii) San Angelo dei Lombardi (AV), SAL; the nitrogen fertilization strategies were: i) fertilized with mineral fertilizers (urea), MIN; ii) fertilized with organic fertilizer Biocor, ORG; iii) not fertilized N0.

The test was carried out on two years (2004-05 and 2005-06) and the variety of durum wheat chosen for experiment was Simeto.

The dose of nitrogen was calculated according to balance method and it was $100 \mathrm{~kg} \mathrm{ha}^{-1}$; for MIN the nitrogen was distributed two times $(30 \%$ at the sowing and $70 \%$ at the tillering-stem elongation), while for ORG, Biocor was entirely distributed at the sowing. Biocor is an organic fertilizer, based on roasted leather with $9 \%$ of organic nitrogen, and it has the characteristic to mineralize slowly, as reported also by Tosti et al. (2016).

Each treatment was replicated three times, for a total of 9 plots per each site, and each plot was $20 \mathrm{~m}^{2}$.

In each experimental site, at the beginning of each year, samplings of soil were made in order to determine the physical and chemical characteristics (Table 1).

According to USDA classification, SAL and AI were clay soils, while SGM was sandy-clay-loam soil. All three sites had a discrete content of total nitrogen and a high content of potassium; moreover, SGM had also a good content of $\mathrm{P}_{2} \mathrm{O}_{5}$ and organic matter.

On the first year, the sowing was made in the beginningDecember at SAL and in mid-December at AI and SGM. The harvests were made on the first ten days of July 2005 in all sites.

On the second year, the sowing was made in the beginningDecember in all three sites; the harvests were made on the first ten days of July 2006.

In both years the sowing was particularly complicated due to the heavy rains.

The phosphorus and potassium supply has not been a need, while the cultural practices (weed and pathogens control) were ordinary.

\section{Growth and yield assessments}

In both years, during the cultivation cycle, five samplings were made in different pheno-phase: i) the tillering (T); ii) the stem elongation (SE); iii) the flowering (F); the milky-ripening (MR); and v) the physiological maturity (PM).

At each destructive sampling, the fresh and dry weight of leaves, culms, and spikes were measured and the data were used to calculate the crop growth rate (CGR).

The CGR was given by:

$$
C G R=\frac{D M 1-D M 2}{T 1-T 2}
$$

where DM1 and DM2 are the dry matter of the plant at time T1 and T2; CGR is expressed as $\mathrm{g} \mathrm{m}^{-2} \mathrm{~d}^{-1}$.

Moreover, in the five samplings, the leaf area was also measured by an electronic area meter (Delta-T Devices Ltd., Cambridge, UK) and the data were expressed as leaf area index 
(LAI), that is the ratio of one-sided green leaf area $\left(\mathrm{m}^{2}\right)$ per unit ground area $\left(\mathrm{m}^{2}\right)$, and it is unitless.

In both years, at the harvest, a $6 \mathrm{~m}^{-2}$ sampling area was cut and weighed; in order to determine the total biomass and grain yield, the spikes were separated from biomass, and grain yield was expressed as tons per hectare. Then, the harvest index was calculated by dividing grain yield per total biomass. Plant height, and number of spikes per square meter were also recorded.

On three samples of 100 seeds per each treatment and replicate, the mean weight of kernels (expressed as g 1000 kernels $^{-1}$ ) and the percentage of vitreous kernels were evaluated by visual inspection.

In addition, hectolitre weight, which is a measure of grain ripening and is expressed in $\mathrm{kg} \mathrm{hL}^{-1}$, protein and gluten content, both expressed in percentage, were determined by automatic analyser NIR Control Plus (ISOELECTRIC, Electronic Instruments).

\section{Statistical analysis}

All data were analysed by SPSS software package (SPSS version 22, Chicago, IL, USA), using a general linear model (GLM). Combined analysis of variance (ANOVA) over two growing seasons (years) was performed for crop growth parameters (CGR and LAI), yield, and quality traits. Means were separated according to the Duncan's multiple range test at $\mathrm{P} \leq 0.05$.

\section{Results}

\section{Climate characteristics of experimental site}

In Figure 1 the two-years climate characteristics of experimental sites are reported for San Giorgio la Molara (1A and 1B), Ariano Irpino (1C and 1D), and Sant'Angelo dei Lombardi (1E and $1 \mathrm{~F})$, respectively.

In both years, the three environments showed a typical climate trend of hilly internal areas, with cold and rainy winters. During the first year the total rainfalls (December-first ten-days July) were 609.2, 479.4, and $624.7 \mathrm{~mm}$, for SAL, AI and SGM, respectively; in the second, they were higher in SAL and AI, 692.4, and 652.7 $\mathrm{mm}$, respectively, and they were similar in SGM $613.6 \mathrm{~mm}$; in both years the rainfalls were distributed enough uniformly during the whole period. During the growing period of the first year the maximum temperatures were $12.3,14.0$, and $13.7^{\circ} \mathrm{C}$ on mean, for SAL, AI, and SGM, respectively (Figure 1A, C, and E), and only at $\mathrm{AI}$, they reached $30^{\circ} \mathrm{C}$ at the end of June. The minimum temperatures were $5.3,6.5$, and $6.3^{\circ} \mathrm{C}$ (Figure $1 \mathrm{~A}, \mathrm{C}, \mathrm{E}$ ) for SAL, AI, and $\mathrm{SGM}$, respectively, and they went down below zero between February and March: the lowest temperatures were $-4.5^{\circ} \mathrm{C}$ and $2.0^{\circ} \mathrm{C}$ in the first ten-days of February at SAL and AI, respectively; and $-2.3{ }^{\circ} \mathrm{C}$ at SGM in the first ten-days of March. During the growing period of the second year the temperatures were on mean slightly lower in all three sites; indeed the maximum temperatures were $11.7,13.4$, and $13.1^{\circ} \mathrm{C}$, and the minimum temperatures were 5.6, 6.2, and $6.1^{\circ} \mathrm{C}$ for SAL, AI, and SGM, respectively (Figure $1 \mathrm{~B}, \mathrm{D}, \mathrm{F})$. However, the cold month of second year was January, but the lowest minimum temperatures did not go down below zero in SGM $\left(0.2^{\circ} \mathrm{C}\right.$ in the second half of January), instead in AI and SAL they reached $-0.8^{\circ} \mathrm{C}$ and $-1.4^{\circ} \mathrm{C}$, in the second and in the third ten-days of January.

\section{Growth indices}

In both years, the wheat growth was recorded during the whole crop cycle, and CGR and LAI were calculated. ANOVA highlighted a significant effect of environment (experimental site) and fertilization strategies on both CGR and LAI, instead the effect of year and the third and second-degree interactions were not found (Table 2).

In the first two pheno-phase intervals, the growth rate of wheat was (mean values of the two years) significantly higher (almost five fold and three fold more, respectively) in SGM than in AI and SAL, which were not different between them; in the last interval, this trend was inverted and the CGR in SGM was statistically lower than the other two sites (Table 3). This behaviour suggests that in both years the crop cycle started and finished earlier in SGM with respect to the other two experimental sites.

The growth rate was higher in both fertilized treatments than not fertilized control from tillering to flowering, but only in the first interval these differences were significant; in the last interval MIN and ORG were lower than the not fertilized control, but without significant differences between them (Table 3).

Table 1. Physical and chemical characteristics of the three experimental sites at the begin of I year (2004-05) and II year (2005-06).

\begin{tabular}{|c|c|c|c|c|c|c|c|}
\hline \multirow[t]{2}{*}{ Texture } & & \multicolumn{2}{|c|}{ AI } & \multicolumn{2}{|c|}{ SGM } & \multicolumn{2}{|c|}{ SAL } \\
\hline & & I year & II year & I year & II year & I year & Il year \\
\hline Coarse sand & $\%$ & 10.5 & 10.0 & 18.5 & 18.3 & 9.9 & 10.1 \\
\hline Fine sand & $\%$ & 18.8 & 18.9 & 28.7 & 28.8 & 22.2 & 22.0 \\
\hline Silt & $\%$ & 26.2 & 25.8 & 26.8 & 26.5 & 24.9 & 24.8 \\
\hline Clay & $\%$ & 44.5 & 45.3 & 26.0 & 26.4 & 43.0 & 43.1 \\
\hline N-Total (Kjeldahl method) & $\mathrm{g} \mathrm{kg}^{-1}$ & 0.88 & 0.86 & 1.15 & 1.13 & 0.93 & 0.92 \\
\hline $\mathrm{P}_{2} \mathrm{O}_{5}$ (Olsen method) & ppm & 17.6 & 19.4 & 37.8 & 45.6 & 19.9 & 24.6 \\
\hline $\mathrm{K}_{2} \mathrm{O}$ (Tetraphenylborate method) & ppm & 235.7 & 257.6 & 350.8 & 356.8 & 220.7 & 248.7 \\
\hline Organic matter (Bichromate method) & $\%$ & 1.01 & 1.07 & 2.52 & 2.45 & 1.67 & 1.59 \\
\hline $\mathrm{NO}_{3}-\mathrm{N}$ & ppm & 3.5 & 4.2 & 18.6 & 17.8 & 4.9 & 5.6 \\
\hline $\mathrm{NH}_{4}-\mathrm{N}$ & ppm & 11.8 & 15.6 & 14.6 & 15.2 & 12.0 & 13.7 \\
\hline $\mathrm{pH}$ & & 7.35 & 7.33 & 7.15 & 7.13 & 7.83 & 7.65 \\
\hline Electrical conductivity & $\mathrm{dS} \mathrm{m}^{-1}$ & 0.152 & 0.161 & 0.238 & 0.229 & 0.164 & 0.159 \\
\hline
\end{tabular}

AI, Ariano Irpino; San SGM, Giorgio La Molara; SAL, Sant’Angelo dei Lombardi. 
The Leaf Area Index is an indicator of green cover of a crop per unit area, and therefore indirectly of crop development; in the current research, the mean LAI value was 0.83 during the whole growing period. Among the three experimental sites, on two years mean SGM had a higher LAI value in the first three samplings and it was significantly different from AI and SAL; on mean of the whole cycle, SGM was three-fold more than the other two sites (Table 4). These findings are also in line with that recorded for
CGR. Regarding the fertilization strategies, in the first three phases both fertilization treatments improved the leaf expansion respect N0 $(+71.0 \%)$, but ORG was not different from it (Table 4).

\section{Yield and its components}

The wheat yield was affected by interaction between experimental sites and fertilization strategies $(\mathrm{S} \times \mathrm{F})$, while the other sec-
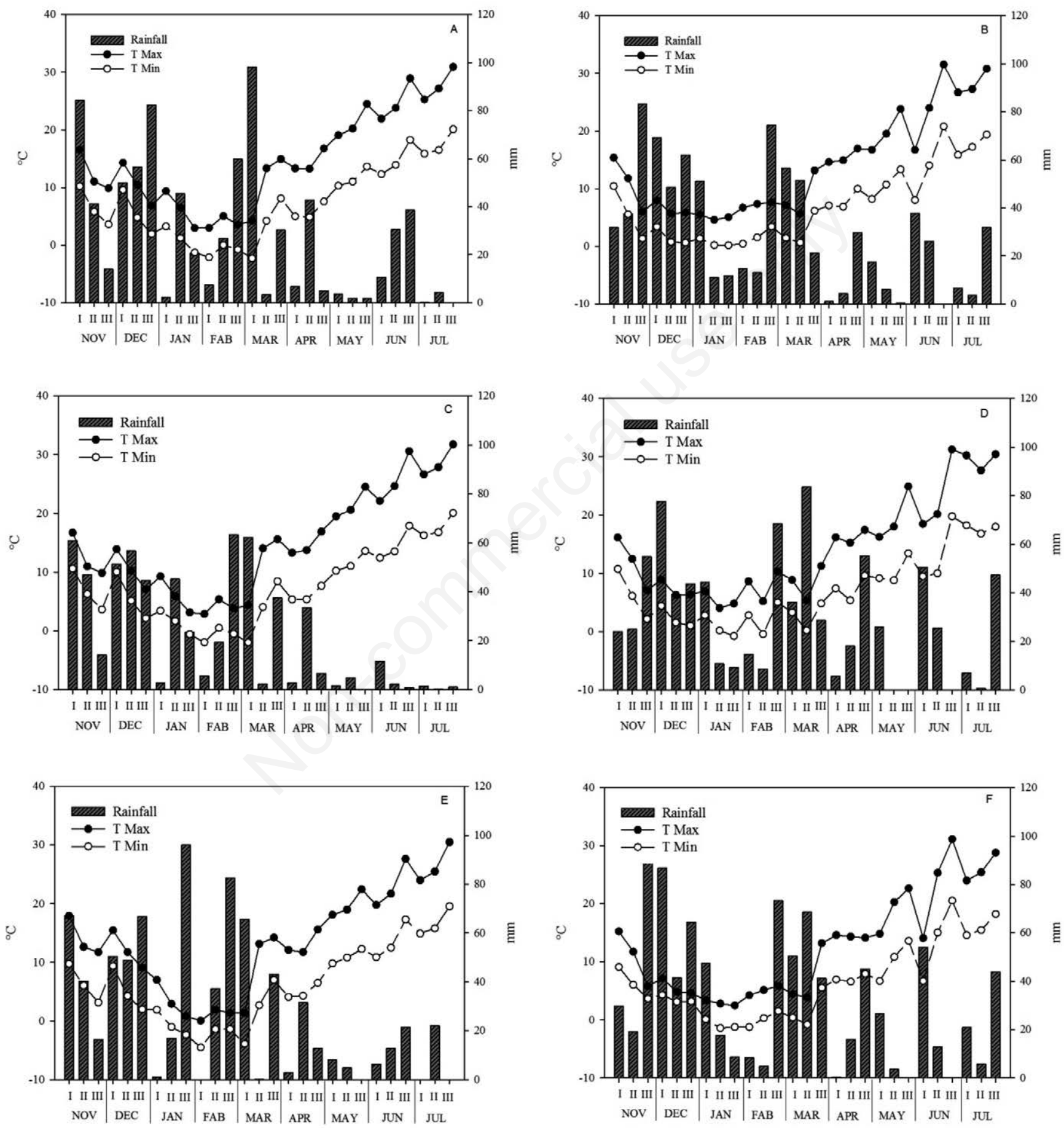

Figure 1. Maximum and minimum air temperature trends, and rainfall during the growing period of wheat in San Giorgio la Molara $(\mathrm{A}=\mathrm{I}$ year; $\mathrm{B}=\mathrm{II}$ year), Ariano Irpino $(\mathrm{C}=\mathrm{I}$ year; $\mathrm{D}=\mathrm{II}$ year $)$, and Sant'Angelo dei Lombardi $(\mathrm{E}=\mathrm{I}$ year; F = II year). 
ond-degree interactions and the third-degree interaction, as well as the main effect of year, were not found (Table 5).

In both years, the mean value of yield was 3.0 tons per hectare; when averaged on two years, the highest yield values were reached at SGM, $3.9 \mathrm{tha}^{-1}$, about $55 \%$ over the mean value of the other two sites $\left(2.5 \mathrm{t} \mathrm{ha}^{-1}\right)$ (Figure 2). Both fertilization treatments (MIN and ORG) had the best performance in San Giorgio La Molara, where they elicited a $4.18 \mathrm{t} \mathrm{ha}^{-1}$ yield and without differences between them. Instead, in the other two sites, MIN was always statistically higher than ORG, about double in $\mathrm{AI}$, and $+31.6 \%$ in SAL. Notably, at SGM the not-fertilized treatment reached a high yield and it was not different from MIN treatment of the other two sites; that confirms the higher natural fertility of SGM soil. Finally, in AI the organic fertilization treatment was not different from the not

Table 2. Analysis of variance of crop growth rate and leaf area index: significance of main factors and interactions.

\begin{tabular}{|c|c|c|c|c|c|c|c|c|}
\hline \multirow[t]{2}{*}{ Significance } & \multicolumn{4}{|c|}{ Crop growth rate } & \multicolumn{4}{|c|}{ Leaf area index } \\
\hline & T-SE & SE-F & F-MR & MR-PR & $\mathrm{T}$ & $\mathrm{SE}$ & $\mathbf{F}$ & MR \\
\hline Years (Y) & - & - & - & - & - & - & - & - \\
\hline Site (S) & 0.01 & 0.01 & - & 0.05 & 0.01 & 0.01 & 0.01 & 0.05 \\
\hline Fertilization (F) & 0.01 & - & - & - & 0.05 & 0.05 & 0.05 & - \\
\hline $\mathrm{Y} \times \mathrm{S}$ & - & - & - & - & - & - & - & - \\
\hline $\mathrm{Y} \times \mathrm{F}$ & - & - & - & - & - & - & - & - \\
\hline $\mathrm{S} \times \mathrm{F}$ & - & - & - & - & - & - & - & - \\
\hline $\mathrm{Y} \times \mathrm{S} \times \mathrm{F}$ & - & - & - & - & - & - & - & - \\
\hline
\end{tabular}

T-SE, tillering-stem elongation; SE-F, stem elongation-flowering; F-MR, flowering-milky ripening; MR-PR, milky-ripening-physiological-ripening.

Table 3. Crop growth rate of wheat as affected by experimental site, and fertilization strategies in four pheno-phase.

\begin{tabular}{lcccc} 
Treatments & \multicolumn{2}{c}{ CGR $\left(\mathrm{g} \mathrm{m}^{-2} \mathrm{~d}^{-1}\right)$} & F-MR & MR-PR \\
AI & T-SE & SE-F & 17.2 & $7.7^{\mathrm{a}}$ \\
SGM & $5.6^{\mathrm{b}}$ & $9.0^{\mathrm{b}}$ & 20.7 & $3.1^{\mathrm{b}}$ \\
\hline SAL & $32.2^{\mathrm{a}}$ & $32.4^{\mathrm{a}}$ & 20.1 & $6.5^{\mathrm{ab}}$ \\
N0 & $7.3^{\mathrm{b}}$ & $11.3^{\mathrm{b}}$ & 17.4 & 7.4 \\
\hline MIN & $9.0^{\mathrm{b}}$ & 15.9 & 21.2 & 4.1 \\
ORG & $18.3^{\mathrm{a}}$ & 18.7 & 19.5 & 5.9 \\
\hline
\end{tabular}

CGR, crop growth rate; AI, Ariano Irpino; SGM, San Giorgio La Molara; SAL, Sant'Angelo dei Lombardi; N0, not fertilized; MIN, fertilized with mineral fertilizer; ORG, fertilized with organic fertilizer; T-SE, tillering-stem elongation; SE-F, stem elongation-flowering; F-MR, flowering-milky ripening; MR-PR, milky-ripening-physiological-ripening. a,b Different letters within each column indicate significant differences according to Duncan's test $(\mathrm{P} \leq 0.05)$.

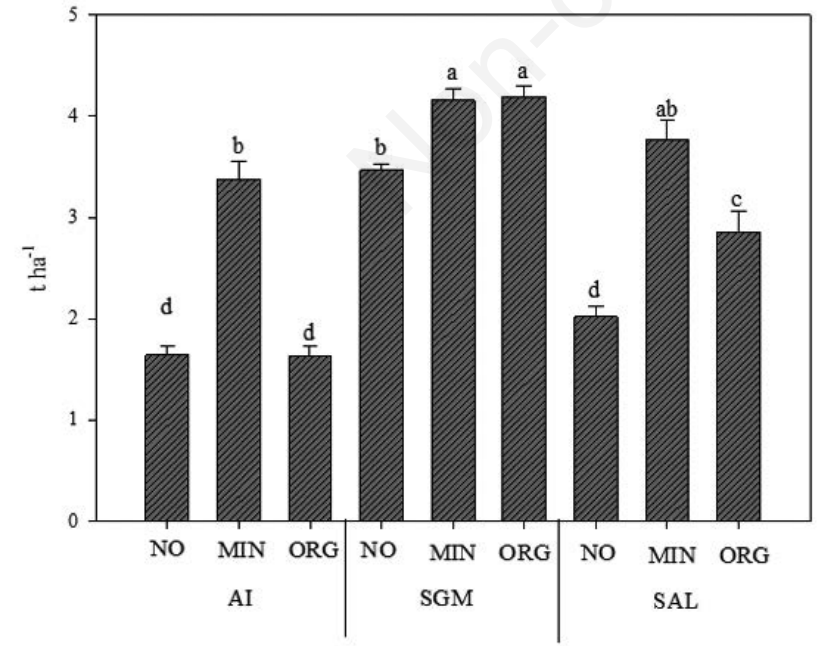

Figure 2. Yield of wheat as affected by experimental site (AI, Ariano Irpino; SGM, San Giorgio La Molara; SAL, Sant'Angelo dei Lombardi) and nitrogen fertilization strategies (N0, not fertilized; MIN, fertilized with mineral fertilizer; ORG, fertilized with organic fertilizer). Different letters indicate significant differences according to Duncan's test $(\mathbf{P}<0.05)$.

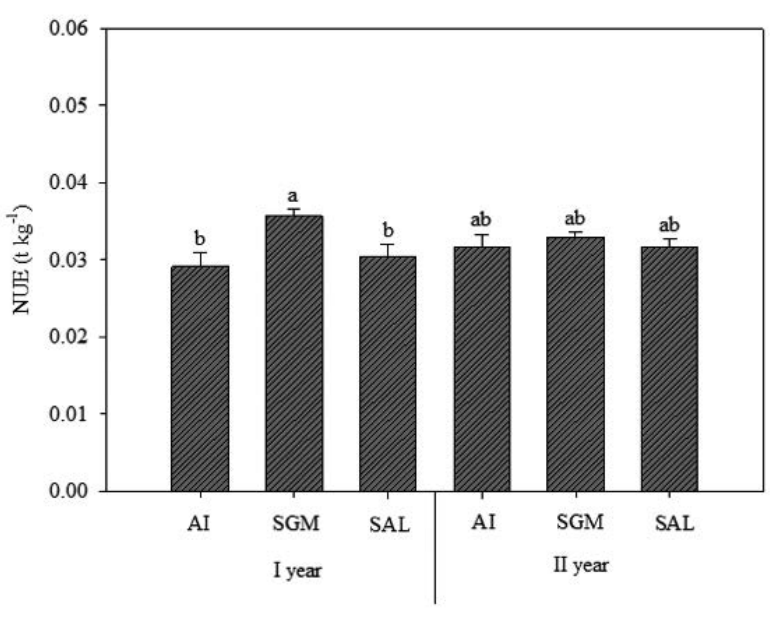

Figure 3. Nitrogen use efficiency (NUE) of wheat as affected by year $(\mathrm{I}$ year $=2004-05$; II year $=2005-06)$ and experimental site (I, Ariano Irpino; SGM, San Giorgio La Molara; SAL, Sant'Angelo dei Lombardi). Different letters indicate significant differences according to Duncan's test $(P<0.05)$. 
fertilized treatment, while in SAL it had an intermediate value between MIN and N0 (Figure 2).

By the statistical analysis, the third-degree interaction was never found for harvest index, number of spikes per square meter, plant height, and 1000 kernels weight, but these last two were affected by the interaction between experimental sites per fertilization strategies $(\mathrm{S} \times \mathrm{F})($ Table 5).

In terms of height, the plants had the best development in SGM, where they had a mean height of $74.4 \mathrm{~cm}$; the plant height was notably lower in AI and SAL: 61.5 and $65.2 \mathrm{~cm}$, respectively, also if at SAL, the MIN plants reached values not different from the SGM plants (Table 6).

The different development of plants in the three sites was reflected in a different harvest index, also if for this parameter the interaction was not found; SGM and AI showed similar values: $63.7 \%$ and $63.8 \%$ vs $57.8 \%$ of SAL (Table 6). Notably, the highest value of HI was recorded for N0, $65.3 \%$ vs about $60.0 \%$ of the other two treatments.

Table 4. Leaf area index of wheat as affected by experimental site, fertilization strategies in four pheno-phase.

\begin{tabular}{|c|c|c|c|c|}
\hline \multirow[t]{2}{*}{ Treatments } & \multicolumn{4}{|c|}{ LAI $\left(m^{2} m^{-2}\right)$} \\
\hline & T-SE & SE-F & F-MR & MR-PR \\
\hline $\mathrm{AI}$ & $0.21^{\mathrm{b}}$ & $0.42^{b}$ & $0.62^{b}$ & $0.55^{\mathrm{ab}}$ \\
\hline SGM & $1.50^{\mathrm{a}}$ & $1.82^{\mathrm{a}}$ & $2.10^{\mathrm{a}}$ & $0.43^{b}$ \\
\hline SAL & $0.27^{\mathrm{b}}$ & $0.52^{\mathrm{b}}$ & $0.76^{b}$ & $0.71^{\mathrm{a}}$ \\
\hline No & $0.36^{\mathrm{b}}$ & $0.59^{\mathrm{b}}$ & $0.91^{b}$ & 0.51 \\
\hline MIN & $0.85^{\mathrm{a}}$ & $1.21^{\mathrm{a}}$ & $1.42^{\mathrm{a}}$ & 0.69 \\
\hline ORG & $0.77^{a b}$ & $0.96^{\mathrm{ab}}$ & $1.15^{\mathrm{ab}}$ & 0.49 \\
\hline
\end{tabular}

LAI, leaf area index; AI, Ariano Irpino; SGM, San Giorgio La Molara; SAL, Sant’Angelo dei Lombardi; N0, not fertilized; MIN, fertilized with mineral fertilizer; ORG, fertilized with organic fertilizer; T, tillering; SE, stem elongation; F, flowering; MR, milky ripening. a,bDifferent letters within each column indicate significant differences according to Duncan's test ( $\mathrm{P} \leq 0.05)$.

Table 5. Analysis of variance of yield and quality parameters: significance of main factors and interactions.

\begin{tabular}{|c|c|c|c|c|c|c|c|c|c|c|}
\hline Significance & Yield & Height & HI & Spikes & Weight & HM & Vitreous & Protein & Gluten & NUE \\
\hline Years $(Y)$ & - & - & - & - & - & - & - & - & - & - \\
\hline Site (S) & 0.01 & 0.01 & 0.01 & 0.01 & 0.01 & 0.01 & 0.01 & 0.01 & 0.01 & 0.01 \\
\hline Fertilization (F) & 0.01 & 0.01 & 0.01 & 0.01 & 0.05 & 0.01 & 0.01 & - & - & 0.01 \\
\hline $\mathrm{Y} \times \mathrm{S}$ & - & - & - & - & - & - & - & - & - & 0.05 \\
\hline $\mathrm{Y} \times \mathrm{F}$ & - & - & - & - & - & - & - & - & - & - \\
\hline $\mathrm{S} \times \mathrm{F}$ & 0.01 & 0.01 & - & - & 0.01 & 0.01 & 0.01 & 0.01 & 0.01 & 0.01 \\
\hline
\end{tabular}

$\mathrm{Y} \times \mathrm{S} \times \mathrm{F}$

$\mathrm{HI}$, harvest index; Spikes, spikes number $\mathrm{m}^{-2}$; Weight, 1000 kernels weight; HM, hectolitre mass; NUE, nitrogen use efficiency.

Table 6. Height, harvest index, number of spikes per square meter and 1000 kernels weight of wheat as affected by experimental site and nitrogen fertilization strategies.

\begin{tabular}{|c|c|c|c|c|c|}
\hline \multicolumn{2}{|c|}{ Treatments } & $\begin{array}{l}\text { Height } \\
\text { cm }\end{array}$ & $\begin{array}{l}\mathrm{HI} \\
\%\end{array}$ & $\begin{array}{l}\text { Spikes } \\
\mathrm{n}^{\circ} \mathrm{m}^{2}\end{array}$ & $\begin{array}{c}\text { Weight } \\
\text { gr } 1000 \text { kernels }^{-1}\end{array}$ \\
\hline $\mathrm{AI}$ & $\begin{array}{l}\text { N0 } \\
\text { MIN } \\
\text { ORG }\end{array}$ & $\begin{array}{c}60.0^{\mathrm{bc}} \\
64.7^{\mathrm{b}} \\
59.8^{\mathrm{bc}}\end{array}$ & $\begin{array}{l}67.4 \\
61.8 \\
62.3\end{array}$ & $\begin{array}{l}263.5 \\
325.0 \\
266.2\end{array}$ & $\begin{array}{l}52.14^{\mathrm{e}} \\
56.50^{\mathrm{d}} \\
55.82^{\mathrm{d}}\end{array}$ \\
\hline SGM & $\begin{array}{l}\text { N0 } \\
\text { MIN } \\
\text { ORG }\end{array}$ & $\begin{array}{l}74.2^{\mathrm{a}} \\
77.0^{\mathrm{a}} \\
72.0^{\mathrm{a}} \\
\end{array}$ & $\begin{array}{l}68.6 \\
60.0 \\
62.6\end{array}$ & $\begin{array}{l}295.1 \\
381.2 \\
392.9 \\
\end{array}$ & $\begin{array}{l}59.73^{\mathrm{bc}} \\
60.04^{\mathrm{bc}} \\
57.52^{\mathrm{cd}}\end{array}$ \\
\hline SAL & $\begin{array}{l}\text { N0 } \\
\text { MIN } \\
\text { ORG }\end{array}$ & $\begin{array}{c}58.3^{\mathrm{c}} \\
74.0^{\mathrm{a}} \\
63.3^{\mathrm{bc}}\end{array}$ & $\begin{array}{l}59.9 \\
56.1 \\
57.5\end{array}$ & $\begin{array}{l}212.5 \\
272.8 \\
210.3\end{array}$ & $\begin{array}{c}63.05^{\mathrm{a}} \\
62.23^{\mathrm{ab}} \\
61.88^{\mathrm{ab}}\end{array}$ \\
\hline $\mathrm{AI}$ & & $61.5^{\mathrm{c}}$ & $63.8^{\mathrm{a}}$ & $284.9^{b}$ & $54.82^{\mathrm{c}}$ \\
\hline SGM & & $74.4^{\mathrm{a}}$ & $63.7^{\mathrm{a}}$ & $356.4^{\mathrm{a}}$ & $59.10^{\mathrm{b}}$ \\
\hline SAL & & $65.2^{\mathrm{b}}$ & $57.8^{\mathrm{b}}$ & $231.9^{c}$ & $62.39^{\mathrm{a}}$ \\
\hline No & & $64.2^{b}$ & $65.3^{\mathrm{a}}$ & $257.0^{\mathrm{b}}$ & $58.31^{\mathrm{b}}$ \\
\hline MIN & & $71.9^{\mathrm{a}}$ & $59.3^{b}$ & $326.3^{\mathrm{a}}$ & $59.59^{\mathrm{a}}$ \\
\hline ORG & & $65.1^{\mathrm{b}}$ & $60.8^{\mathrm{b}}$ & $289.8^{\mathrm{ab}}$ & $58.41^{\mathrm{b}}$ \\
\hline
\end{tabular}

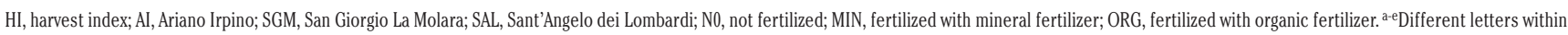
each column indicate significant differences according to Duncan's test $(\mathrm{P} \leq 0.05)$. 
Finally, both fertilization treatments increased the number of spikes per square meter, but ORG was not different also from control not fertilized; the highest value of this parameter was recorded in SGM, while AI showed an intermediate value, and SAL was significantly lower than the other two treatments (Table 6).

In SAL, the 1000 kernel weight reached the highest values, without differences between the three fertilization treatments; however, MIN and ORG of SAL were not different also from N0 and MIN of SGM; in AI, the lowest values of 1000 kernels were recorded (54.82 vs 59.10 and 62.39 of SGM, and SAL, respectively) (Table 6).

\section{Yield quality}

In order to evaluate the grain quality, hectolitre mass, percentage of vitreous kernels, protein and gluten percentage of wheat kernels were measured; by statistical analysis, it resulted that all parameters were affected by the interaction between experimental site and fertilization strategies, but the other second-degree interactions and the third-degree interaction were not significant (Table 5).

The hectolitre mass is a measure of the volume of grain per unit and it is usually expressed as kilograms per hectolitre; this parameter is a good indication of grain-soundness and it is usually used as an indication of expected flour yield.

Once again, at SGM the hectolitre weight reached a higher value than the other two sites: 83.73 vs 82.89 (mean value of AI and SAL); however, in AI, the organic fertilization was not different from N0 and MIN of SGM (Table 7).

The protein percentage in grain reached the higher values in AI (13.5\%) and SGM (13.4\%) with respect to $12.2 \%$ of SAL; moreover, in all three sites no differences between the two fertilization treatments were found, but ORG had the lowest value in AI and the highest in SGM (Table 7).

For gluten percentage, the best performance was recorded in $\mathrm{AI}$ and SGM, where the mean value was $11.7 \%$, while in SAL the gluten percentage was $9.3 \%$ on mean, and here N0 had a different behaviour with respect to the other two sites, showing the lowest value (Table 7).

Finally, the worst values of the vitreous kernels percentage were recorded in SAL (52.3\%), where they were about double the value of SGM (26.1\%), and six-fold more than that of AI $(8.2 \%)$ (Table 7).

\section{Nitrogen use efficiency}

Regarding the nitrogen use efficiency (NUE), statistical analy- sis highlighted the interaction between years and experimental sites $(\mathrm{Y} \times \mathrm{S})$ and between experimental site and fertilization strategies $(\mathrm{S} \times \mathrm{F})($ Table 5$)$.

In both years, when averaged on experimental sites, the NUE value was $0.032 \mathrm{t} \mathrm{kg}^{-1}$, but in the first year SGM reached the highest and significantly different value with respect to the other two sites $\left(0.036\right.$ vs $\left.0.030 \mathrm{t} \mathrm{kg}^{-1}\right)$; in the second year there were not differences between the experimental sites which were not different from both SGM-I year and all other treatments, showing intermediate values (Figure 3).

Instead regarding the interaction experimental site and fertilization strategies, in all three sites the not fertilized treatment elicited the highest value, and without differences only between SGM and AI; the NUE of the two fertilized treatments of SGM was $0.025 \mathrm{t} \mathrm{kg}^{-1}$ and they were not different between them and from both MIN treatment of SAL and AI, and Org treatment of SAL (Figure 4). The ORG treatment of AI showed the worst performance in terms of NUE (Figure 4).

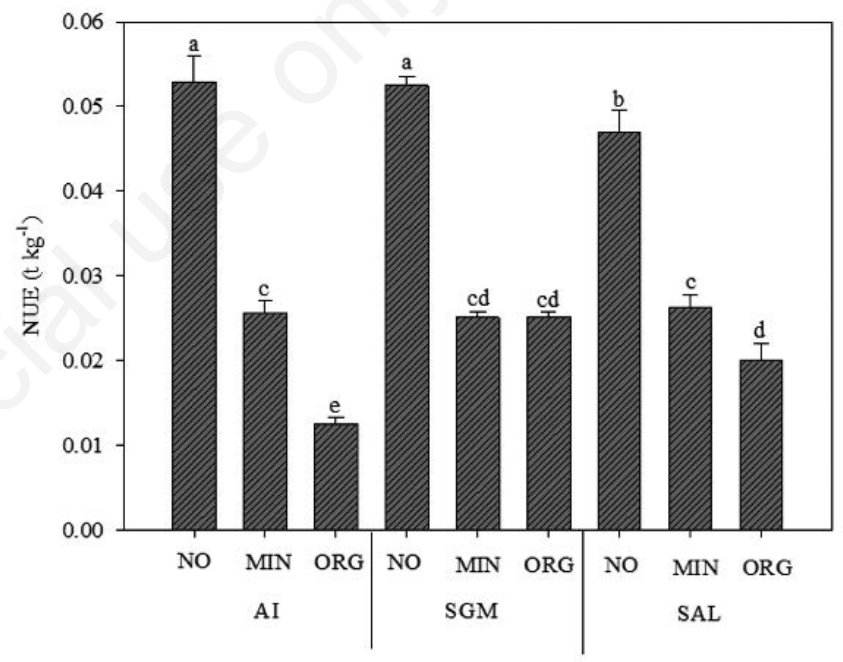

Figure 4. Nitrogen use efficiency (NUE) of wheat as affected by experimental site (AI, Ariano Irpino; SGM, San Giorgio La Molara; SAL, Sant'Angelo dei Lombardi) and nitrogen fertilization strategies (N0, not fertilized; MIN, fertilized with mineral fertilizer; ORG, fertilized with organic fertilizer). Different letters indicate significant differences according to Duncan's test $(\mathbf{P}<0.05)$.

Table 7. Hectolitre mass, vitreousness, and protein and gluten content of wheat as affected by experimental site and nitrogen fertilization strategies.

\begin{tabular}{|c|c|c|c|c|c|}
\hline Treatments & & 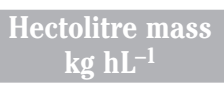 & $\begin{array}{c}\text { Vitreousness } \\
\%\end{array}$ & $\begin{array}{c}\text { Protein } \\
\%\end{array}$ & $\begin{array}{l}\text { Gluten } \\
\%\end{array}$ \\
\hline $\mathrm{AI}$ & $\begin{array}{l}\text { N0 } \\
\text { MIN } \\
\text { ORG }\end{array}$ & $\begin{array}{c}80.69^{\mathrm{e}} \\
82.63^{\mathrm{d}} \\
84.16^{\mathrm{ab}}\end{array}$ & $\begin{array}{c}6.0^{\mathrm{e}} \\
3.3^{\mathrm{e}} \\
15.3^{\mathrm{d}}\end{array}$ & $\begin{array}{c}13.7^{\mathrm{a}} \\
13.7^{\mathrm{a}} \\
13.2^{\mathrm{ab}}\end{array}$ & $\begin{array}{c}12.4^{\mathrm{a}} \\
12.3^{\mathrm{ab}} \\
10.4^{\mathrm{ce}}\end{array}$ \\
\hline SGM & $\begin{array}{l}\text { N0 } \\
\text { MIN } \\
\text { ORG }\end{array}$ & $\begin{array}{c}84.47^{\mathrm{a}} \\
83.92^{\mathrm{ac}} \\
82.80^{\mathrm{d}}\end{array}$ & $\begin{array}{l}27.5^{\mathrm{c}} \\
20.2^{\mathrm{d}} \\
30.6^{\mathrm{c}}\end{array}$ & $\begin{array}{c}13.3^{\mathrm{ab}} \\
13.1^{\mathrm{ab}} \\
13.9^{\mathrm{a}}\end{array}$ & $\begin{array}{l}11.3^{\text {ad }} \\
11.0^{\text {bd }} \\
11.5^{\text {ac }}\end{array}$ \\
\hline SAL & $\begin{array}{l}\text { N0 } \\
\text { MIN } \\
\text { ORG }\end{array}$ & $\begin{array}{l}83.23^{\mathrm{cd}} \\
83.37^{\mathrm{bd}} \\
83.29^{\mathrm{bd}}\end{array}$ & $\begin{array}{l}42.9^{\mathrm{b}} \\
56.4^{\mathrm{a}} \\
57.6^{\mathrm{a}}\end{array}$ & $\begin{array}{c}11.7^{\mathrm{c}} \\
12.5^{\mathrm{bc}} \\
12.5^{\mathrm{bc}}\end{array}$ & $\begin{array}{c}8.5^{\mathrm{f}} \\
9.3^{\text {ef }} \\
10.2^{\text {de }}\end{array}$ \\
\hline
\end{tabular}

AI, Ariano Irpino; SGM, San Giorgio La Molara; SAL, Sant'Angelo dei Lombardi; N0, not fertilized; MIN, fertilized with mineral fertilizer; ORG, fertilized with organic fertilizer. a-fDifferent letters within each column indicate significant differences according to Duncan's test $(\mathrm{P} \leq 0.05)$. 


\section{Discussion}

The results of current research demonstrate that environment, therefore soil and climatic characteristics, and type of nitrogen fertilization strongly affect growth, yield, and quantitative and qualitative components of durum wheat. Other authors also found a significant effect of environmental conditions on these parameters (Campbell et al., 1981; Garrido-Lestache et al., 2005; Barraclough et al., 2010), as well as Rossini et al. (2018) which found a yield variability on year and hypothesized that it may be due to different amount and distribution of rainfall during the crop cycle, as suggested by López-Bellido et al. (1996).

In the same way, we also found a strong effect of environment on most of the analysed parameters, both single and combined effect (second-degree interaction) with the type of fertilization. The three environments of the test were different among them in terms of both climatic and soil conditions. AI and SAL were clay soils with about $1.0 \%$ and $1.6 \%$ of organic matter, respectively; instead, SGM was a sandy-clay-loam soil with a high value of organic matter $(2.5 \%)$. Regarding climate conditions, SAL resulted colder than SGM and AI in both years: a two-year temperature mean value was $8.7^{\circ} \mathrm{C}$ vs $9.8^{\circ} \mathrm{C}$ and $10.0^{\circ} \mathrm{C}$ of $\mathrm{SGM}$ and $\mathrm{AI}$, respectively. In addition, SAL also showed a greater rainfall on the two years average, it was about $651.0 \mathrm{~mm}$ in the growing period with respect to $619.0 \mathrm{~mm}$ and $566.0 \mathrm{~mm}$ of SGM and AI, respectively. These conditions strongly affected the growth and yield of wheat; in SGM the plants grew better and faster (higher values of CGR), especially until flowering: the CGR of SGM was about 2.5fold more than the mean value of CGR of AI and SAL recorded in the three first pheno-phases. Similarly, in terms of LAI, the more favourable conditions of SGM elicited higher values than AI and SAL, about four-fold more, and always until to flowering. The most favourable conditions of SGM (high fertility, better soil texture, and better climate) also boosted yield with a 55.0\% increase over the mean value of AI and SAL; the effect also interested the yield of the not fertilized control, which was not different from the MIN treatment of AI and SAL.

Our findings highlighted a site-specific response of wheat to different strategies of fertilization; indeed, in SGM, organic and mineral fertilization had the same performance, instead in the other two site, the organic fertilization always depressed yield. In SAL, the yield of plants fertilized with roasted leather was $31.6 \%$ lower than the yield of plants subjected to mineral fertilization, in line with the $30.0 \%$ decrease reported by Seugfert et al. (2012). In AI, yield of ORG was about half of the yield of MIN; probably this decrease was due to lower rainfall recorded in AI, which also caused a low value of thousand kernels weight, in line with the findings of Rossini et al. (2018) which reported a significant yield decrease in the driest year, regardless fertilization and varieties. Ercoli et al. (2011) also reported a notable sensitivity of medium and late-maturing varieties to water shortage, instead any differences between wet and dry season did not find for early or medium-early varieties. Other authors also reported a decrease in yield of the short-cycle cultivars with the decrease of the rainfall amount in the Mediterranean environment (Garrido-Lestache et al., 2005; Flagella et al., 2010).

Our findings regarding the specific response of wheat to organic fertilization in AI and SAL are in line with the results of previous research (Černý et al., 2010; Tosti et al., 2016) which recorded yields up to $19 \%$ lower in organically fertilized than mineral fertilized wheat. In particular, Tosti et al. (2016) confirmed the best yield performance of mineral nitrogen fertilization as compared to organic fertilization, especially when roasted leather was used. Indeed, the findings of this research highlighted the diverse behaviour of different organic fertilizers (blood meal and roasted leather) in the function of their mineralization rate (faster in the first one) and climatic conditions. Also Černý et al. (2010) compared different forms of organic fertilization (sewage sludge, farmyard manure, and straw of spring barley) with the mineral fertilization and not fertilized, in five sites with different soil-climatic conditions on three years rotation (potato, winter wheat, and spring barley). They found that in all sites any types of fertilization improved yield with respect to the not fertilized control, but among the different types of fertilization, the organic fertilization showed the worst performance. Moreover, in the site with higher fertility $(\mathrm{C}=2.6 \%)$ the yield increase over the not fertilized control due to the several types of fertilization was less marked, similarly to that we found in SGM.

Obviously, the productive response of durum wheat to fertilization also reflects the different growth and developments of plants under different growth conditions. Fertilization treatment positively affected the plant development, both MIN and ORG boosted CGR and LAI with respect to the not fertilized treatment, but the increase in LAI of ORG over N0 was less marked; indeed, the CGR values were $15.6,15.3$, and $12.4 \mathrm{~g} \mathrm{~m}^{-2} \mathrm{~d}^{-1}$, and the LAI values $1.04,0.84$, and 0.59 , for $\mathrm{MIN}, \mathrm{ORG}$, and $\mathrm{N} 0$, respectively.

Opposite to our findings, Tuttobene et al. (2009) found that the best performance of crop growth (LAI and CGR) was recorded in organic fertilization, but this contrasting result is probably due to the different organic fertilizer used in the experiment; they tested orange waste, that has a high content of organic carbon (46\%) and nitrogen $(14.5 \%)$, and probably it mineralizes into the soil faster than roasted leather, that has a slow rate of mineralization as also reported by Tosti et al. (2016).

The harvest index (HI) is the rate between yield and total biomass; the higher HI of the not fertilized treatments suggest that probably these plants used the available nitrogen in the soil mainly for sustaining yield more than crop growth.

On the other hand, our findings on nitrogen use efficiency highlighted that in all environments the not fertilized treatments had higher values than the other treatments, but in SAL it was significantly lower $(-11.3 \%)$ than the mean value of AI and SGM. Thus, we assume a site-specific response; indeed, in SGM, a site with high fertility, the NUE value of the two fertilized treatments was not different. Instead, organic fertilization showed a lower NUE value compared to MIN both in AI and SAL, but in AI this decrease was higher: it was about half of MIN.

Regardless of the nitrogen fertilization, the two-years mean value of NUE in SGM was slightly higher than the values of AI and SAL: $0.034,0.031$, and $0.030 \mathrm{t} \mathrm{kg}^{-1}$, respectively.

The different efficiency of nitrogen use in the different sites is probably due to different climatic conditions. Tosti et al. (2016) reported that the effect of organic fertilization on wheat $\mathrm{N}$ uptake depends on the variable availability of the soil mineral $\mathrm{N}$ at sowing and on drainage timing and intensity. It is known that in the autumn-winter months, the mineralization rate is low due to low temperatures and high water content in the soil influencing oxygen concentration, but Magid et al. (2001) found that nitrogen is released in soil with low temperatures (also below $5^{\circ} \mathrm{C}$ ). Therefore the difference in nitrogen availability depends both on the mineralization of organic substance and the leaching phenomenon; in fact, in rainy environments, the risks of leaching nitrogen are higher, especially when precipitations are concentrated in a short time.

In our research, the three sites were notably different among them, both for physical and chemical properties of soils and for cli- 
mate (temperatures and rainfall) conditions. SGM had the higher content of N-total (1.14 vs 0.87 , and $0.92 \mathrm{~g} \mathrm{~kg}^{-1}$ of AI and SAL, respectively), and organic matter $(2.48 \%$ vs $1.04 \%$, and $1.63 \%$ of $\mathrm{AI}$ and SAL, respectively). In addition, the different soil textures of the three sites could justify their different behaviour towards water content in the soil. Indeed, in SGM the higher content of sand could have avoided an excessive water stagnation with consequent higher oxygen concentration in soil, which favoured mineralization of organic matter. The best performance of ORG in SAL with respect to AI could be due to its higher fertility (higher content of nitrogen and organic matter), which best sustained growth and yield from the beginning of the cycle, therefore increasing also NUE.

On the other hand, in AI and SGM we observed higher values of protein and gluten percentage $(13.5 \%$ and $11.5 \%$ vs $12.2 \%$, and $9.3 \%$ of SAL, respectively). In SGM this finding can be explained by the high fertility of the site; instead, in AI we suppose that the lower rainfall combined with a higher temperature with respect to SAL boosted mineralization of organic matter, by making available higher nitrogen content but only in the last phases of the cycle, therefore improving quality traits but not the yield.

For durum wheat destined for pasta production some traits of quality, including protein and gluten percentage, are essential in order to obtain a final product with a high qualitative standard and that reflects the quality of the raw material. El-Khayat et al. (2006) reported that not only the abundance but also the relative content of specific gluten protein fractions are important traits for wheat quality, which vary depending on fertilization techniques and changes in environmental conditions during grain filling. Tosti et al. al (2016) found that the grain protein content of the plants with organic fertilization was lower than that of the plants to which added mineral fertilizers and, in addition, the fertilization with roasted leather reached lower values than the fertilization with blood meal (8.65\% vs $9.06 \%$ mean of three years). Rossini et al. (2018) found a lower value of grain protein content in organic fertilization as compared to mineral fertilization, too. Instead, we did not observe a strong effect of fertilization on protein and gluten percentage, while the environmental effect was more marked. Indeed, no differences were recorded between ORG and MIN in terms of protein percentage in all three sites; regarding the gluten percentage, only in AI, ORG was significantly lower than MIN in line with the results of Fagnano et al. (2012). These findings could be linked to the limited nitrogen availability during the crop reproductive phases that reduces the protein accumulation in grains (Woese et al., 1997). Our results are in line with the findings of Marinaccio et al. (2016) which determined that on silty-clay-loam soil the grain protein content was lower in the year with high rainfall. Also Rharrabti et al. (2003), in a study carried out in different zones, latitudes, and water regimes (irrigated and rainfed) of Spain for evaluating their effects on the quality of ten different durum wheat genotypes, found that grain protein content, as such as vitreousness, showed better values under low moisture regimes, unlike the thousand kernels weight. We also found the higher values of vitreousness in higher rainfall conditions (SAL); on the other hand, it is already known that vitreousness is highly influenced by environmental conditions (mainly water availability) (Robinson et al., 1979; Gooding and Davies, 1997).

\section{Conclusions}

Our findings highlight a great environmental effect on the growth, nitrogen use efficiency, yield, and quality of durum wheat cultivated in marginal lands, such as the internal hill of Southern Italy.

The soil properties play a key role in crop agronomic response; indeed, in soils with a high content of nitrogen and organic matter, and lower content of clay, growth, and yield showed the best performance, also in not-fertilized plants.

In addition, the total rainfall and its distribution seem to strongly affect the nitrogen availability during the whole crop cycle; in areas with lower precipitations, yield decrease occurred but some quality traits, such as grain protein percentage and vitreousness improved. In these conditions, the effect of fertilization is also less strong, indeed plants organically fertilized do not reach a yield level greater than not fertilized plants.

Overall, the effect of nitrogen fertilization type results site-specific; indeed, organic fertilization had the same performance of mineral in the site with better soil (low clay content, high nitrogen, and organic matter content) and climate conditions.

However, it is also conceivable a different behaviour of different typologies of organic fertilizer.

Therefore, the use of organic fertilization in marginal areas assumes a good knowledge of the dynamics of organic matter mineralization and climate characteristics of the zone; thus, it seems necessary to do further researches in different lands and using different organic fertilizers.

\section{References}

Barraclough PB, Howarth JR, Jones J, Lopez-Bellido R, Parmar S, Shepherd CE, Hawkesford MJ, 2010. Nitrogen efficiency of wheat: genotypic and environmental variation and prospects for improvement. Eur. J. Agron. 33:1-11.

Berry PM, Sylvester-Bradley R, Philipps L, Hatch DJ, Cuttle SP, Rayns FW, Goslin P, 2002. Is the productivity of organic farms restricted by the supply available nitrogen? Soil Use Manage. 18:248-55.

Campbell CA, Davidson HR, Winkleman GE, 1981. Effect of nitrogen, temperature, growth stage and duration of moisture stress on yield components and protein content of manitou spring wheat. Can. J. Plant Sci. 61:549-63.

Černý J, Balík J, Kulhánek M, Čásová K, Nedvěd V, 2010. Mineral and organic fertilization efficiency in long-term stationary experiments. Plant Soil Environ. 56:28-36.

Commission Regulation (EC) No. 889/2008 of 5 September 2008 laying down detailed rules for the implementation of Council Regulation EC No 834/2007 on organic production and labelling of organic products with regard to organic production, labelling, and control. Off. J. Eur. Union L 250(18):1-84.

David C, Jeuffroy MH, Laurent F, Mangin M, Meynard JM, 2005. The assessment of Azodyn-Org model for managing nitrogen fertilization of organic winter wheat. Eur. J. Agro. 23:225-42.

El-Khayat GH, Samaan, J, Manthey FA, Fuller MP, Brennan CS, 2006. Durum wheat quality I: Correlations between physical and chemical characteristics of Syrian durum wheat cultivars. Int J. of Food Sci. Tech. 41:22-9.

Ercoli L, Lulli L, Arduini I, Mariotti M, Masoni A, 2011. Durum wheat grain yield and quality as affected by $\mathrm{S}$ rate under Mediterranean conditions. Eur. J. Agron. 35:63-70.

Fagnano M, Fiorentino N, D’Egidio MG, Quaranta F, Ritieni A, Ferracane R, Raimondi G, 2012. Durum wheat in conventional and organic farming: yield amount and pasta quality in 
Southern Italy. Sci. World J. 1:9.

Flagella Z, Giuliani MM, Giuzio L, Volpi C, Masci S. 2010. Influence of water deficit on durum wheat storage protein composition and technological quality. Eur. J. Agron. 33:197207.

Garrido-Lestache E, López-Bellido RJ, López-Bellido L, 2005. Durum wheat quality under Mediterranean conditions as affected by $\mathrm{N}$ rate, timing and splitting, $\mathrm{N}$ form and $\mathrm{S}$ fertilization. Eur. J. Agron. 23:265-78.

Gooding MJ, Davies WP, 1997. Wheat production and utilization: systems, quality and the environment. CAB International, Wallingford.

Kho RM, 2000. On crop production and the balance of available resources. Agr. Ecosyst. Environ. 80:1-2.

López-Bellido L, Fuentes M, Castillo J, López-Garrido F, Fernández E, 1996. Long-term tillage, crop rotation, and nitrogen fertilizer effects on wheat yield under rainfed Mediterranean conditions. Agron. J. 88:783-91.

Mader P, Hahn D, Dubois D, Gunst L, Alfoldi T, Bergmann H, 2007. Wheat quality in organic and conventional farming: Results of a 21year field experiment. J. Sci. Food Agr. 87:1826-35.

Magid J, Henriksen O, Thorup-Kristensen K, Mueller T, 2001. Disproportionately high $\mathrm{N}$-mineralisation rates from green manures at low temperatures- implications for modeling and management in cool temperate agro-ecosystems. Plant Soil. 228:73-82.

Marinaccio F, Blandino M, Reyneri A, 2016. Effect of nitrogen fertilization on yield and quality of durum wheat cultivated in Northern Italy and their interaction with different soils and growing seasons. J. Plant Nutr. 39:643-54.

Mehmood MA, Ibrahim M, Rashid U, Nawaz M, Ali S, Hussain A, Gull M, 2017. Biomass production for bioenergy using marginal lands. Sustain. Prod. Consumpt. 9:3-21

Mondini C, Cayuela ML, Sinicco T, Sanchez-Monedero MA, Bertolone E, Bardi L, 2008. Soil application of meat and bone meal. Short-term effects on mineralization dynamics and soil biochemical and microbiological properties. Soil Biol.
Biochem. 40:462-74

Nocente F, De Stefanis E, Ciccoritti R, Pucciarmati S, Taddei F, Campiglia E, Mancinelli R, 2019. How do conventional and organic management affect the healthy potential of durum wheat grain and semolina pasta traits? Food Chem. 297:124884.

Ravindran B, Nagalakshmi C, Devi SG, Subramanian KS, Mandal AB, Sekaran G, 2013. Efficiency of hydrolyzed tannery solid waste for the growth and yield potentials on tomato. J. Plant Nutr. 36:795-810.

Rharrabti Y, Royo C, Villegas D, Aparicio N, García del Moral LF, 2003. Durum wheat quality in Mediterranean environments I. Quality expression under different zones, latitudes and water regimes across Spain. Field Crops Res. 80:123-31.

Robinson FE, Cudney DW, Lehman WF, 1979. Nitrate fertilizer timing, irrigation, protein and yellow berry in durum wheat. Agron. J. 71:304-608.

Rossini F, Provenzano ME, Sestili F, Ruggeri R, 2018. Synergistic effect of sulphur and nitrogen in the organic and mineral fertilization of durum wheat: grain yield and quality traits in the Mediterranean environment. Agronomy, 8:189.

Seufert V, Ramankutty N, Foley JA, 2012. Comparing the yields of organic and conventional agriculture. Nature 229-31.

Tosti G, Farneselli M, Benincasa P, Guiducci M, 2016. Nitrogen fertilization strategies for organic wheat production: crop yield and nitrate leaching. Agron. J. 108:770-81.

Tuttobene R, Avola G, Gresta F, Abbate V, 2009. Industrial orange waste as organic fertilizer in durum wheat. Agron. Sustain. Develop. 29:557-63.

Ventrella D, Stellacci AM, Castrignano A, Charfeddine M, Castellini M, 2016. Effects of crop residue management on winter durum wheat productivity in a long term experiment in Southern Italy. Eur. J. Agro. 77:188-98.

Woose K, Lange D, Boess C, and Bögl KW, 1997. A comparison of organically and conventionally grown foods: results of a review of the relevant literature? J. Sci. Food Agric. 74:281-93. 